\title{
Ecology of Children's Growth: An Example from Transitional Populations of the Brazilian Amazon
}

\author{
Hilton P. Silva • Douglas E. Crews
}

Received: 18 October 2005 / Accepted: 10 August 2006 /

Published online: 15 November 2006

(C) Springer Science + Business Media B.V. 2006

\begin{abstract}
The intense environmental and social changes taking place in Amazonia make this a key area for health studies of populations transitioning to a cosmopolitan lifestyle and market economy. Caboclos are among those populations. They comprise the majority of rural Brazilian Amazon peoples. At present there is limited information about their patterns of growth and health. In this paper, anthropometric data on Caboclo children from three groups living in different environments are presented and discussed within a bioanthropological framework. Caxiuanã, Aracampina, and Santana have a combined population of 1,069 people. Caxiuanã relies more on subsistence activities for survival and Santana more on commerce, while Aracampina uses both subsistence strategies. Compared to US children, Caboclo are generally shorter and lighter in all age groups. However, their weightfor-height is above the 50th percentile. In relation to skinfolds, age groups $0-2,6-8$, and 9-11 years present statistically significant differences among the three communities. Caxiuanã children have the smallest and Aracampina children have the largest skinfolds. While seasonal and environmental differences may account for some of the observed variation in growth and fatness patterns, socioeconomic factors also play a key role in the trends observed. Thus, an ecological model provides the best framework for explaining these findings. Caxiuanã children are small and thin as a result of their combined poor environment and limited access to cash, western goods, and health care. Aracampina and Santana's fuller access to such socioeconomic influences and richer ecology results in taller and fatter children. Understanding similar interactions between ecology and social factors will be fundamental to developing sustainable health initiatives among rural Amazonian populations.
\end{abstract}

Keywords Caboclos $\cdot$ Health $\cdot$ Stunting $\cdot$ Pará $\cdot$ Rural populations

A previous version of this paper was presented at the XV ICAES, Florence, Italy, 2003.

H. P. Silva $(\bowtie)$

Museu Nacional/UFRJ, Departamento de Antropologia, Setor de Antropologia Biológica,

Quinta da Boa Vista s/n, 20940-040 Rio de Janeiro, RJ, Brazil

e-mail: hdasilva@acd.ufrj.br

D. E. Crews

Department of Anthropology, The Ohio State University, Columbus, OH 43210-1364, USA 


\section{Introduction}

Rural populations of the Brazilian Amazon are often called Caboclos [26, 44, 49, 50]. They resulted from admixture among Portuguese colonizers, escaped or freed African slaves, and native South Amerindians living along the Amazon River and its tributaries in Brazil. These populations have increased in numbers and in importance in the Amazon since the rubber boom of the late 19th century $[7,33,49,50]$. Today, Caboclos comprise the majority of the riverine peasant populations in Northern Brazil [44]. Nevertheless, little is yet known about many aspects of their life, health, and modes of interaction with the environment.

Research has established that health and disease are associated closely with adequate levels of nutrition as availability and access to food are major determinants of individual survival [20, 40]. During childhood, humans are extremely sensitive to nutritional deficiencies and related diseases, as throughout the growth process, all biological systems require a constant and regular inflow of nutrients to develop properly [5, 11]. The consequences of nutritional deficits occurring during growth resonate throughout an individual's entire life $[4,6,9,12,32]$.

Several attempts have been made to describe the general nutritional status and growth characteristics of Brazil's children and adults [8, 21, 22, 29, 30]. In general, research in the country has concentrated on areas with higher population densities, such as São Paulo, Rio de Janeiro, Belo Horizonte, and the Northeastern states. No extensive and reliable reports exist on health and growth characteristics of children in rural areas of the Amazon basin $[23,45]$. In addition, there are some bioanthropological studies focusing on the health and/ or growth characteristics of Caboclo groups [1, 35, 38, 42-44, 46-48].

In this paper, we characterize the growth and nutritional situation of Caboclo children and examine the influences of sex, age, and place of residency on these measures. The focus is on groups living in three areas in the state of Pará, Brazil, with different ecosystems, subsistence strategies, and degrees of contact with the market economy. In general, it is hypothesized that the level of involvement of Caboclo populations with market economy is associated with negative influences on the patterns of health and growth of their children. This hypothesis is tested using data collected in the three Caboclo groups during the rainy and the dry seasons, between 1996 and 1997.

\section{Samples}

The three groups studied, include approximately 1,069 people, of whom approximately $40 \%$ are children 11 years old or younger. Although the groups studied live in different environments, leading to somewhat different lifestyles, they share most of their traditions, customs, and culture, and a similar genetic background, composed of European, Amerindian, and African ancestors.

\section{Caxiuanã}

Caxiuanã $(N=212)$ is the least studied population. This group lives in the Caxiuanã National Forest $\left(1^{\circ} 42^{\prime} 30^{\prime \prime} \mathrm{S}, 51^{\circ} 31^{\prime} 45^{\prime} \mathrm{W}\right)$ a protected area in the heart of the rainforest. The nearest town to Caxiuanã is Portel, $9 \mathrm{~h}$ west by motorboat [27]. The group lives in an area of relatively acidic black waters in the Caxiuanã bay. Their subsistence is mainly based on manioc (Manihot esculenta), bananas (Musa sp.), and tropical fruit, with fish and hunted 
game, and extraction of natural products such as Brazil nuts (Bertoletia excelsia). Occasionally, the diet is complemented with a variety of packaged products such as pasta, crackers, canned meats, rice, beans, and sometimes free-range chicken, duck, or pig. With the exception of an increased consumption of açaí (Euterpe olleracea) during the dry season, there are no major changes in the diet of Caxiuanã dwellers from the wet to the dry season. Caxiuanã reflects a more traditional lifestyle because its population has few and limited interactions with local markets [44, 45].

\section{Aracampina and Santana}

The other two populations in the study are situated on Ituqui Island, Santarém county, Pará $\left(20^{\circ} 30^{\prime} \mathrm{S}, 54^{\circ} \mathrm{E} 30^{\prime} \mathrm{W}\right)$. Ituqui is located $3 \mathrm{~h}$ downstream by boat from Santarém, in the Tapajós river, a white water ecosystem. Because the Island's communities are more fully integrated into the local market economy, they represent a more transitional population, although as rural groups, they are not subject to the additional stressors of an urban environment.

Aracampina $(N=380)$ is the community most affected by seasonality. The entire village is flooded during the wet season [24, 28]. Subsistence resources come mainly from fishing, subsistence agriculture, and a few retirement pensions. This population's diet is based on manioc flour, fish, and rice, complemented with chicken, pork or game and, more rarely, beef. In the wet season, diet is more varied and includes packaged products such as crackers, tinned foods, powdered milk, and pasta [36, 44].

Santana $(N=477)$ is the most westernized of the groups due to its population size, infrastructure, and the intense contact and commerce it maintains with Santarém. Subsistence activities in Santana include agriculture, fishing, commerce, retirement pensions, and a few white-collar jobs in the school and the health post. In the dry season, diet in Santana is based on fish, manioc flour, and rice with other products such as beef, game meat, chicken, beans, and pasta added occasionally. As in Aracampina, during the wet season more packaged products such as powdered milk and chocolate, crackers, pasta, and tinned foods are added to meals, which are also complemented with seasonal fruits. Coffee with sugar is consumed regularly in all three groups [36, 44].

\section{Materials and Methods}

Data to evaluate physical growth, nutritional situation, and body habitus were collected following internationally accepted standard procedures $[13,19,51]$. All data were collected twice, once in the dry season, and again in the wet season.

The six anthropometric measurements used in this study (height, weight, upper arm circumference, triceps, subscapular and suprailiac skinfolds) are the basic set recommended and used by most authors in the field $[13,15]$. All measurements were collected by the first author to avoid inter-observer errors. Over $85 \%$ of the children ages $0-11$ years of the three populations were measured in both seasons.

Body composition was calculated using the following information from the anthropometric data [13]:

Sum of skinfolds $($ Sumskfd $)=$ triceps + subscapular + supra iliac

Arm fat index $(\mathrm{AFI})=(\mathrm{UAFA} / \mathrm{TUAA}) \times 100$

Upper arm fat area (UAFA) $=$ TUAA-UAMA 
Total upper arm area (TUAA) $=$ upper arm circumference ${ }^{2} /(4 \times \pi)$

Upper arm muscle area $($ UAMA $)=[\text { upper } \operatorname{arm} \operatorname{circ}-(\operatorname{triceps} \times \pi)]^{2} /(4 \times \pi)$

To facilitate statistical analysis, comparison of height-for-age, weight-for-age, and weight-for-height with international reference data [37] was conducted with Aracampina and Santana combined (then called Ituqui), and Caxiuanã. Further analyses were conducted with the three groups separated. Methods of analysis included $Z$ scores, with a cut-off point of $-2 Z$ scores for short and low-weight individuals [31, 52], $t$ tests, and multiple regression.

\section{Results}

There are no statistically significant differences between boy's and girl's heights, weights, skinfolds, upper arm fat area (UAFA), upper arm muscle area (UAMA), or arm fat index (AFI) by age group (data not shown). In the dry season, children from Caxiuanã are shorter and lighter than children from Aracampina and Santana in all age groups. In the wet season the trend is more complex. Caxiuanã children are shorter than Aracampina and Santana children, but at ages 0-2 years they are heavier than Santana children, and at ages 3-5 and 6-8 years they are heavier than Aracampina's children. In the dry season, arm circumferences of Caxiuanã children are smaller than Aracampina's and Santana's in all age groups, except in the 6-8 years group. In the wet season, Caxiuanã children have larger arm circumferences than Aracampina's and Santana's in age groups 0-2 and 6-8 years, but not at ages 3-5 and 9-11 years. Aracampina children are heavier and have larger arm circumferences than Santana's at ages 0-2 in the wet season, but the trend is not consistent in the dry season or in other age groups.

Statistically, there are no significant differences in the percent of children per-Z-score category between Caxiuanã and the two groups from Ituqui (Table 1). Because $64.5 \%$ of the children were measured twice, the effect of season on their growth can be evaluated using $Z$ scores. As there are no statistically significant differences in mean $Z$ scores between boys and girls in any community, the sexes were combined and then divided by age groups for further analysis.

Table 1 Percent distribution of children (0-11 years old) by season of the year, according to $Z$ scores of height-for-age (HAZ), weight-for-age (WAZ), and weight-for-height (WHZ), sexes combined.

\begin{tabular}{|c|c|c|c|c|c|c|c|}
\hline \multicolumn{4}{|c|}{ Caxiuanã } & \multicolumn{4}{|l|}{ Ituqui } \\
\hline$Z$ score & $\leq-2$ & $-1.99-0$ & $>0$ & $\leq-2$ & $-1.99-0$ & $>0$ & $p$ value \\
\hline \multicolumn{8}{|c|}{ Dry season } \\
\hline HAZ & 79.6 & 18.7 & 1.7 & 72.1 & 26.9 & 1.0 & 0.11 \\
\hline WAZ & 34.8 & 62.1 & 3.1 & 26.6 & 66.8 & 6.6 & 0.58 \\
\hline WHZ & 0.0 & 26.6 & 73.4 & 1.4 & 36.4 & 62.2 & 0.50 \\
\hline \multicolumn{8}{|c|}{ Wet season } \\
\hline HAZ & 80.3 & 19.7 & 0.0 & 72.3 & 26.1 & 1.6 & 0.16 \\
\hline WAZ & 31.1 & 66.2 & 2.7 & 23.8 & 69.6 & 6.6 & 0.28 \\
\hline WHZ & 0.0 & 19.3 & 80.7 & 2.1 & 29.9 & 68.0 & 0.19 \\
\hline
\end{tabular}

$P$ values (based on $t$ test) for differences between groups 
Mean combined height-for-age $Z$ scores in Caxiuanã do not change significantly between the wet and the dry seasons $(p=0.14)$, but both weight-for-age and weight-forheight $Z$ scores are statistically different between the dry and wet seasons $(p=0.05, p=0.02$, respectively; Table 2, Part I). In Ituqui, average height-for-age and weight-for-age $Z$ scores differ significantly between wet and dry seasons $(p<0.01, p=0.01$; Table 2, Part I). When boys and girls are separated, a slightly different picture emerges with mean $Z$ scores in the dry season lower and closer to zero, than in the wet season in all groups (Table 2, Part II). The pairwise comparison of $Z$ scores for Caxiuanã shows a statistically significant difference in height-for-age between the dry and wet seasons in boys $(p=0.02)$.

In Ituqui, height-for-age and weight-for-height of boys are significantly different between the seasons $(p=0.01$, and $p=0.02)$ and so is height-for-age of girls $(p=0.02$; Table 2, Part II). Mean $Z$ scores for height-for-age, weight-for-age, and weight-for-height in the two seasons were compared across populations. Overall, Caxiuanã children have higher

Table 2 Means, standard deviations of height-for-age (HAZ), weight-for-age (WAZ), and weight-for-height (WHZ) $Z$ scores of children ages $0-11$, by group. $P$ values (based on paired $t$ tests) for differences between seasons with sexes combined (part I), with sexes separated (part II), and among groups per season of the year (part III).

\begin{tabular}{|c|c|c|c|c|c|c|c|c|c|}
\hline \multirow[t]{2}{*}{ Part I } & & \multicolumn{4}{|c|}{ Caxiuanã } & \multicolumn{4}{|l|}{ Ituqui } \\
\hline & & $N$ & Mean & SD & $P$ & $N$ & Mean & $\mathrm{SD}$ & $P$ \\
\hline \multirow[t]{2}{*}{ Pair 1} & HAZ (dry season) & 56 & -3.02 & 1.19 & 0.14 & 160 & -2.61 & 0.96 & 0.00 \\
\hline & HAZ (wet season) & 56 & -3.12 & 1.37 & & 160 & -2.31 & 1.57 & \\
\hline \multirow[t]{2}{*}{ Pair 2} & WAZ (dry season) & 61 & -1.55 & 0.83 & 0.05 & 170 & -1.49 & 0.86 & 0.01 \\
\hline & WAZ (wet season) & 61 & -1.67 & 0.93 & & 170 & -1.39 & 0.80 & \\
\hline \multirow[t]{2}{*}{ Pair 3} & WHZ (dry season) & 48 & 0.64 & 0.71 & 0.02 & 141 & 0.31 & 0.99 & 0.49 \\
\hline & WHZ (wet season) & 48 & 0.40 & 0.78 & & 141 & 0.36 & 0.80 & \\
\hline \multicolumn{2}{|l|}{ Part II } & \multicolumn{4}{|c|}{ Caxiuanã } & \multicolumn{4}{|l|}{ Ituqui } \\
\hline \multicolumn{2}{|l|}{ Males } & $N$ & Mean & $\mathrm{SD}$ & $P$ & $\mathrm{~N}$ & Mean & $\mathrm{SD}$ & $P$ \\
\hline \multirow[t]{2}{*}{ Pair 1} & HAZ (dry season) & 30 & -3.07 & 1.36 & 0.02 & 83 & -2.67 & 0.91 & 0.01 \\
\hline & HAZ (wet season) & 30 & -3.24 & 1.41 & & 83 & -2.56 & 0.93 & \\
\hline \multirow[t]{2}{*}{ Pair 2} & WAZ (dry season) & 32 & -1.57 & 0.85 & 0.11 & 89 & -1.45 & 0.87 & 0.09 \\
\hline & WAZ (wet season) & 32 & -1.71 & 1.03 & & 89 & -1.32 & 0.79 & \\
\hline \multirow[t]{2}{*}{ Pair 3} & WHZ (dry season) & 27 & 0.63 & 0.66 & 0.15 & 81 & 0.49 & 0.88 & 0.02 \\
\hline & WHZ (wet season) & 27 & 0.43 & 0.80 & & 81 & 0.64 & 0.78 & \\
\hline \multicolumn{2}{|l|}{ Females } & $N$ & Mean & $\mathrm{SD}$ & $P$ & $\mathrm{~N}$ & Mean & $\mathrm{SD}$ & $P$ \\
\hline \multirow[t]{2}{*}{ Pair 1} & HAZ (dry season) & 26 & -2.96 & 1.00 & 0.81 & 77 & -2.56 & 1.01 & 0.02 \\
\hline & HAZ (wet season) & 26 & -2.99 & 1.32 & & 77 & -2.04 & 2.03 & \\
\hline \multirow[t]{2}{*}{ Pair 2} & WAZ (dry season) & 29 & -1.52 & 0.82 & 0.26 & 81 & -1.56 & 0.85 & 0.07 \\
\hline & WAZ (wet season) & 29 & -1.63 & 0.82 & & 81 & -1.47 & 0.82 & \\
\hline \multirow[t]{2}{*}{ Pair 3} & WHZ (dry season) & 21 & 0.65 & 0.79 & 0.07 & 60 & 0.12 & 1.09 & 0.58 \\
\hline & WHZ (wet season) & 21 & 0.36 & 0.77 & & 60 & 0.17 & 0.88 & \\
\hline \multirow[t]{8}{*}{ Part III } & & & \multicolumn{3}{|c|}{ Caxiuanã } & \multicolumn{4}{|l|}{ Ituqui } \\
\hline & & & Mean & SD & & Mean & SD & & $P$ \\
\hline & HAZ (dry season) & & -1.10 & 4.57 & & -0.10 & 5.07 & & 0.11 \\
\hline & HAZ (wet season) & & -0.18 & 5.68 & & 0.80 & 5.57 & & 0.16 \\
\hline & WAZ (dry season) & & -0.53 & 3.35 & & 0.47 & 4.39 & & 0.05 \\
\hline & WAZ (wet season) & & 0.51 & 4.62 & & 1.16 & 4.82 & & 0.28 \\
\hline & WHZ (dry season) & & 2.40 & 4.07 & & 2.77 & 4.33 & & 0.50 \\
\hline & WHZ (wet season) & & 2.78 & 4.21 & & 3.53 & 4.60 & & 0.19 \\
\hline
\end{tabular}


Table 3 Means, standard deviations, and $p$ values (based on paired $t$ tests) for comparisons of height-for-age (HAZ), weight-for-age (WAZ), and weight-for-height (WHZ) $Z$ scores of children ages 0-11 from Caxiuanã, Aracampina, and Santana between seasons, by age group with males and females combined.

\begin{tabular}{|c|c|c|c|c|c|c|c|c|c|c|c|c|c|}
\hline & \multirow[b]{2}{*}{ Age Group } & \multicolumn{4}{|c|}{ Caxiuanã } & \multicolumn{5}{|c|}{ Aracampina } & \multicolumn{3}{|c|}{ Santana } \\
\hline & & $N$ & Mean & $\mathrm{SD}$ & $p$ & $\mathrm{~N}$ & Mean & $\mathrm{SD}$ & $p$ & $\mathrm{~N}$ & Mean & $\mathrm{SD}$ & $p$ \\
\hline & $0-2$ years & & & & & & & & & & & & \\
\hline \multirow[t]{2}{*}{ Pair 1} & HAZ (dry season) & 12 & -2.90 & 1.37 & 0.90 & 12 & -2.92 & 1.37 & 0.90 & 23 & -3.17 & 1.24 & 0.37 \\
\hline & HAZ (wet season) & 12 & -2.95 & 1.34 & & 12 & -2.95 & 1.34 & & 23 & -2.91 & 1.05 & \\
\hline \multirow[t]{2}{*}{ Pair 2} & WAZ (dry season) & 16 & -1.54 & 1.08 & 0.89 & 15 & -1.68 & 0.97 & 0.93 & 31 & -1.57 & 1.21 & 0.96 \\
\hline & WAZ (wet season) & 16 & -1.57 & 0.98 & & 15 & -1.66 & 0.95 & & 31 & -1.57 & 1.06 & \\
\hline \multirow[t]{3}{*}{ Pair 3} & WHZ (dry season) & 12 & 0.18 & 0.84 & 0.93 & 12 & 0.16 & 0.84 & 0.92 & 23 & 0.18 & 1.50 & 0.70 \\
\hline & WHZ (wet season) & 12 & 0.21 & 0.90 & & 12 & 0.19 & 0.90 & & 23 & 0.17 & 1.09 & \\
\hline & $3-5$ years & & & & & & & & & & & & \\
\hline \multirow[t]{2}{*}{ Pair 1} & HAZ (dry season) & 16 & -3.80 & 1.71 & 0.28 & 16 & -3.89 & 1.71 & 0.26 & 34 & -2.79 & 0.92 & 0.00 \\
\hline & HAZ (wet season) & 16 & -3.50 & 1.10 & & 16 & -3.71 & 1.39 & & 34 & -2.57 & 1.04 & \\
\hline \multirow[t]{2}{*}{ Pair 2} & WAZ (dry season) & 17 & -2.18 & 1.44 & 0.04 & 17 & -2.10 & 1.04 & 0.04 & 36 & -1.61 & 0.94 & 0.14 \\
\hline & WAZ (wet season) & 17 & -1.94 & 0.87 & & 17 & -1.84 & 0.97 & & 36 & -1.51 & 0.87 & \\
\hline \multirow[t]{3}{*}{ Pair 3} & WHZ (dry season) & 16 & 0.56 & 0.68 & 1.32 & 16 & 0.26 & 0.86 & 1.31 & 34 & 0.13 & 0.84 & 0.88 \\
\hline & WHZ (wet season) & 16 & 0.49 & 0.60 & & 16 & 0.59 & 0.60 & & 34 & 0.12 & 0.78 & \\
\hline & $6-8$ years & & & & & & & & & & & & \\
\hline \multirow[t]{2}{*}{ Pair 1} & HAZ (dry season) & 17 & -2.70 & 0.85 & 0.07 & 17 & -2.69 & 0.88 & 0.06 & 53 & -2.43 & 0.86 & 0.06 \\
\hline & HAZ (wet season) & 17 & -2.60 & 0.76 & & 17 & -2.62 & 0.76 & & 53 & -2.33 & 0.75 & \\
\hline \multirow[t]{2}{*}{ Pair 2} & WAZ (dry season) & 17 & -1.45 & 0.78 & 0.00 & 17 & -1.40 & 0.73 & 0.00 & 53 & -1.44 & 0.69 & 0.15 \\
\hline & WAZ (wet season) & 17 & -1.35 & 0.57 & & 17 & -1.22 & 0.65 & & 53 & -1.35 & 0.64 & \\
\hline \multirow[t]{3}{*}{ Pair 3} & WHZ (dry season) & 17 & 0.60 & 0.85 & 0.00 & 17 & 0.60 & 0.65 & 0.00 & 53 & 0.33 & 0.86 & 0.33 \\
\hline & WHZ (wet season) & 17 & 0.95 & 0.35 & & 17 & 0.93 & 0.53 & & 53 & 0.44 & 0.74 & \\
\hline & $9-11$ years & & & & & & & & & & & & \\
\hline \multirow[t]{2}{*}{ Pair 1} & HAZ (dry season) & 11 & -2.88 & 1.11 & 0.22 & 3 & -3.18 & 1.65 & 0.67 & 48 & -2.43 & 0.83 & 0.00 \\
\hline & HAZ (wet season) & 11 & -2.72 & 0.96 & & 3 & -3.15 & 1.74 & & 48 & -2.29 & 0.78 & \\
\hline \multirow[t]{2}{*}{ Pair 2} & WAZ (dry season) & 11 & -1.63 & 0.61 & 0.37 & 3 & -1.54 & 1.09 & 0.77 & 48 & -1.40 & 0.70 & 0.00 \\
\hline & WAZ (wet season) & 11 & -1.57 & 0.45 & & 3 & -1.59 & 0.82 & & 48 & -1.24 & 0.72 & \\
\hline \multirow[t]{2}{*}{ Pair 3} & WHZ (dry season) & 3 & 0.96 & 0.44 & 0.94 & 3 & 0.96 & 0.44 & 0.94 & 31 & 0.65 & 0.82 & 0.03 \\
\hline & WHZ (wet season) & 3 & 0.99 & 0.48 & & 3 & 0.97 & 0.46 & & 31 & 0.82 & 0.84 & \\
\hline
\end{tabular}

negative mean $Z$ scores than Ituqui children for all three markers. However, mean heightfor-age $Z$ scores do not differ statistically between Caxiuanã and Ituqui in either season. Mean weight-for-age $Z$ scores are significantly different in the dry $(p=0.05)$, but not in the wet season $(p=0.28)$, and weight-for-height $Z$ score differences between groups are not significantly different in any of the seasons (Table 2, Part III).

When the mean $Z$ scores of the three communities, by age group, are compared between the dry and the wet seasons using paired $t$ tests, few differences emerge. Generally, mean $Z$ scores in the dry season are lower than in the wet season for height-for-age, weight-for-age, and weight-for-height, but most of the differences do not reach statistically significant levels (Table 3). Differences are statistically significant in weight-for-age $(p<0.001)$ and weight-for-height in Caxiuanã $(p<0.001)$, and Aracampina $(p<0.001)$. In both cases, a higher negative mean $Z$ score is observed in weight-for-age in the dry season, and a higher positive mean $Z$ score is observed in weight-for-height in the wet season (Table 3 ). In the 9-11 age group, differences between seasons are statistically significant in height-for-age, weight-for-age, and weight-for-height, but only in Santana $(p<0.001, p>0.001, p=0.03$, 
respectively). Height-for-age and weight-for-age present a higher mean negative $Z$ score in the dry season, and a higher positive mean $Z$ score in weight-for-height in the wet season (Table 3).

When the children of the three populations are combined and analyzed through multiple regression of height, weight, and anthropometric indices per age group, it is shown that in the youngest age group ( $0-2$ years) values are not associated with place of residency or sex. But in the older age groups $(3-5,6-8,9-11$ years) some relationships appear (Table 4). Sex is strongly associated with AFI in the age groups 3-5 years $(p<0.001, p<0.001$, dry and wet seasons, respectively), 6-8 years $(p=0.02, p<0.001$, dry and wet seasons, respectively), and 9-11 years ( $p=0.02, p<0.001$, dry and wet seasons, respectively), the boys' values being always higher than the girls'. Sum of skinfolds is also strongly associated with sex in the age groups $3-5$ years $(p=0.01, p=0.01$, dry and wet seasons, respectively), 6-8 years ( $p<0.001, p<0.001$, dry and wet seasons, respectively), and 911 years $(p=0.05, p<0.001$, dry and wet seasons, respectively), also with boy's values higher than girls'.

Additionally, UAFA is strongly associated with sex in the $3-5(p=0.02)$, and $6-8$ age groups $(p=0.01)$ in the wet season, with boy's values higher than girls'. Finally, UAMA is associated with sex in the age groups $3-5$ years in the wet season $(p=0.01), 6-8$ years in the dry season $(p=0.02)$, and 9-11 years in both seasons $(p=0.01, p<0.001$, dry and wet seasons, respectively; Table 4). In the case of UAMA, girls' mean values are overall higher than boys'.

Place of residency has a strong influence on height of the $3-5$ age group ( $p=0.02$, dry season), with the Caxiuanã children being, on average, $5 \mathrm{~cm}$ shorter than the children from Ituqui (Table 4). In the 9-11 years, the children from Caxiuanã are, on average, $3 \mathrm{~cm}$ shorter than the Aracampina and $5 \mathrm{~cm}$ shorter than the Santana children, in the dry and wet seasons ( $p=0.01, p=0.03$, respectively). In relation to weight, the 9-11 age group children from Caxiuanã are significantly lighter than the Santana children in both seasons $(p=0.04$, $p=0.04)$. In relation to AFI, the 6-8 and $9-11$ age groups from Caxiuanã present significantly lower mean values than the Ituqui groups, in the dry season $(p=0.01, p<$ 0.001 , respectively). The mean sum of skinfolds of the 6-8 and 9-11 age groups are higher in Ituqui than in Caxiuanã in the dry season $(p<0.001, p<0.001)$. The mean UAFA of the 9-11 age group from both Ituqui communities are significantly higher than the mean of the Caxiuanã children in the dry season $(p=0.03)$; and the mean UAMA values of the $6-8$ and $9-11$ age groups from Caxiuanã are higher than those from Ituqui in the dry season $(p=$ $0.02, p=0.03$, respectively; Table 4).

\section{Discussion}

When compared to the NCHS/WHO reference data, children from Caxiuanã, Aracampina, and Santana are shorter and lighter than the 50th percentile of the reference, while their weight-forheight is above the 50th percentile. The same trends are present in both seasons of the year.

In Brazil, there are no general updated growth charts based on the national population. However, some research exists which allows comparisons with growth characteristics of children from different parts of the country and also from other countries.

Engstron and Anjos [10], examining childhood stunting and their mother's nutritional status in a general sample of the Brazilian population, observed $14.4 \%$ of stunting ( $15.9 \%$ boys and $12.9 \%$ girls), and a strong association between mothers' educational 
Table 4 Multiple linear regression model with height, weight, arm fat index (AFI), sum of skinfolds (Sumskfd), upper arm fat area (UAFA), and upper arm muscle area (UAMA) of children (0-11 years old), per age group, as dependent variables, and sex and community (place) as independent variables.

\begin{tabular}{|c|c|c|c|c|c|c|c|}
\hline Age group (years) & Variable & $F$ & $\mathrm{p}$ & Age group (years) & Variable & $F$ & $\mathrm{p}$ \\
\hline \multicolumn{5}{|l|}{ Sex/Height } & \multicolumn{3}{|l|}{ Place/Height } \\
\hline \multirow[t]{2}{*}{$0-2$} & Dry season & 1.61 & 0.21 & $0-2$ & Dry season & 0.42 & 0.52 \\
\hline & Wet season & 0.01 & 0.91 & & Wet season & 1.15 & 0.29 \\
\hline \multirow[t]{2}{*}{$3-5$} & Dry season & 0.50 & 0.48 & $3-5$ & Dry season & 5.21 & 0.02 \\
\hline & Wet season & 1.82 & 0.18 & & Wet season & 3.25 & 0.78 \\
\hline \multirow[t]{2}{*}{$6-8$} & Dry season & 0.35 & 0.55 & $6-8$ & Dry season & 2.39 & 0.12 \\
\hline & Wet season & 0.61 & 0.43 & & Wet season & 2.07 & 0.15 \\
\hline \multirow[t]{2}{*}{$9-11$} & Dry season & 0.00 & 0.92 & $9-11$ & Dry season & 6.17 & 0.01 \\
\hline & Wet season & 0.48 & 0.49 & & Wet season & 4.56 & 0.03 \\
\hline \multicolumn{5}{|l|}{ Sex/Weight } & Place/Weight & & \\
\hline \multirow[t]{2}{*}{$0-2$} & Dry season & 1.34 & 0.25 & $0-2$ & Dry season & 0.14 & 0.70 \\
\hline & Wet season & 5.73 & 0.02 & & Wet season & 0.04 & 0.83 \\
\hline \multirow[t]{2}{*}{$3-5$} & Dry season & 0.24 & 0.62 & $3-5$ & Dry season & 2.40 & 0.12 \\
\hline & Wet season & 0.03 & 0.85 & & Wet season & 0.45 & 0.50 \\
\hline \multirow[t]{2}{*}{$6-8$} & Dry season & 3.35 & 0.07 & $6-8$ & Dry season & 0.79 & 0.37 \\
\hline & Wet season & 2.97 & 0.08 & & Wet season & 0.10 & 0.74 \\
\hline \multirow[t]{2}{*}{$9-11$} & Dry season & 0.84 & 0.36 & $9-11$ & Dry season & 4.22 & 0.04 \\
\hline & Wet season & 0.00 & 0.99 & & Wet season & 4.06 & 0.04 \\
\hline \multicolumn{5}{|l|}{ Sex/AFI } & Place/AFI & & \\
\hline \multirow[t]{2}{*}{$0-2$} & Dry season & 2.78 & 0.10 & $0-2$ & Dry season & 0.48 & 0.49 \\
\hline & Wet season & 0.00 & 0.95 & & Wet season & 0.01 & 0.89 \\
\hline \multirow[t]{2}{*}{$3-5$} & Dry season & 9.36 & 0.00 & $3-5$ & Dry season & 2.92 & 0.09 \\
\hline & Wet season & 10.56 & 0.00 & & Wet season & 0.05 & 0.82 \\
\hline \multirow[t]{2}{*}{$6-8$} & Dry season & 5.33 & 0.02 & $6-8$ & Dry season & 6.53 & 0.01 \\
\hline & Wet season & 13.98 & 0.00 & & Wet season & 1.55 & 0.21 \\
\hline \multirow[t]{2}{*}{$9-11$} & Dry season & 5.22 & 0.02 & $9-11$ & Dry season & 8.57 & 0.00 \\
\hline & Wet season & 9.66 & 0.00 & & Wet season & 0.25 & 0.61 \\
\hline \multicolumn{5}{|l|}{ Sex/Sumskfd } & \multicolumn{3}{|c|}{ Place/Sumskfd } \\
\hline \multirow[t]{2}{*}{$0-2$} & Dry season & 3.29 & 0.07 & $0-2$ & Dry season & 0.25 & 0.62 \\
\hline & Wet season & 0.05 & 0.81 & & Wet season & 2.35 & 0.13 \\
\hline \multirow[t]{2}{*}{$3-5$} & Dry season & 6.40 & 0.01 & $3-5$ & Dry season & 3.70 & 0.06 \\
\hline & Wet season & 6.79 & 0.01 & & Wet season & 1.27 & 0.26 \\
\hline $6-8$ & Dry season & 7.72 & 0.00 & $6-8$ & Dry season & 12.4 & 0.00 \\
\hline & Wet season & 7.38 & 0.00 & & Wet season & 2.91 & 0.09 \\
\hline $9-11$ & Dry season & 3.88 & 0.05 & $9-11$ & Dry season & 9.12 & 0.00 \\
\hline & Wet season & 10.50 & 0.00 & & Wet season & 2.45 & 0.12 \\
\hline Sex/UAFA & & & & & Place/UAFA & & \\
\hline $0-2$ & Dry season & 0.23 & 0.62 & $0-2$ & Dry season & 0.16 & 0.68 \\
\hline & Wet season & 0.96 & 0.33 & & Wet season & 0.13 & 0.72 \\
\hline $3-5$ & Dry season & 2.44 & 0.12 & $3-5$ & Dry season & 0.41 & 0.52 \\
\hline & Wet season & 5.20 & 0.02 & & Wet season & 0.07 & 0.78 \\
\hline $6-8$ & Dry season & 1.79 & 0.18 & $6-8$ & Dry season & 2.31 & 0.13 \\
\hline & Wet season & 6.20 & 0.01 & & Wet season & 0.22 & 0.63 \\
\hline $9-11$ & Dry season & 1.78 & 0.18 & $9-11$ & Dry season & 4.63 & 0.03 \\
\hline & Wet season & 2.81 & 0.10 & & Wet season & 0.98 & 0.32 \\
\hline Sex/UAMA & & & & & Place/UAMA & & \\
\hline $0-2$ & Dry season & 3.69 & 0.06 & $0-2$ & Dry season & 0.24 & 0.62 \\
\hline & Wet season & 2.66 & 0.11 & & Wet season & 0.08 & 0.77 \\
\hline $3-5$ & Dry season & 3.27 & 0.07 & $3-5$ & Dry season & 1.79 & 0.18 \\
\hline
\end{tabular}


Table 4 (continued)

\begin{tabular}{llllllll}
\hline Age group (years) & Variable & $F$ & $\mathrm{p}$ & Age group (years) & Variable & $F$ & $\mathrm{p}$ \\
\hline \multirow{4}{*}{$6-8$} & Wet season & 6.60 & 0.01 & & Wet season & 0.13 & 0.71 \\
& Dry season & 5.01 & 0.02 & $6-8$ & Dry season & 5.16 & 0.02 \\
\multirow{3}{*}{$9-11$} & Wet season & 2.92 & 0.09 & & Wet season & 1.36 & 0.24 \\
& Dry season & 6.52 & 0.01 & $9-11$ & Dry season & 4.54 & 0.03 \\
& Wet season & 9.49 & 0.00 & & Wet season & 0.54 & 0.46 \\
\hline
\end{tabular}

level and stunting. In a case-control study of 264 children attending first grade in Osasco city, São Paulo state, Lei et al. [25] identified strong associations of mother's level of schooling, environmental sanitation, and family income with stunting. No direct relationships between education or income and nutritional status were observed among the three study groups [44]. However, it was observed that Caboclo, with more access to educational and economic resources (Santana), present lower disease rates and a more varied diet. In addition, the children from the two Ituqui groups are generally taller and heavier than Caxiuanã children, the group with lower economic resources.

In urban areas of Rio de Janeiro, Anjos et al. [3] reported on growth, AFI, and UAMA of children of different SES. Nutritional status and SES were significantly correlated. Similar to data reported here, age-specific patterns (curves) of AFI and UAMA were similar among boys and girls. Additionally, UAMA of boys were consistently higher than girls, independent of SES, while undernutrition in the low SES group was $6.25 \%$ for stunting, and $3.52 \%$ for wasting, versus $0.5 \%$ for stunting and no wasted child in the higher SES group [3]. In contrast to Caxiuanã, the urban sample examined by Anjos et al., [3] received daily dietary supplementation in the form of school meals, and likely had more access to health care. The overall percents of both stunting and wasting in Rio de Janeiro and Osasco children were lower than those observed among the Caboclos.

Alencar et al. [2] examined 283 children ( $0-5$ years old) from rural and urban areas in Amazonas state, and found $31.1 \%$ with low height-for-age, but low weight-for-height was observed in only $4.2 \%$. Among urban children, undernutrition reached $41.7 \%$, but in rural areas the incidence was only $25.6 \%$. They further report that children were particularly affected by undernutrition in their first year of life, possibly associated with weaning, a common finding [11,33]. According to Alencar et al. [2], although low weight-for-height was more prevalent in children 1 year old or less, low height-for-age was more prevalent in older children. In addition, they reviewed other data suggesting variable prevalence of undernutrition in urban areas of Amazonas, such as São Gabriel da Cachoeira (35.6\%) and Novo Airão (49\%). Overall, rates of undernutrition in urban areas are lower than are observed in the Caboclo.

Giugliano et al. [16] investigated 69 children between 7 and 11 years of age of low SES in the city of Manaus; $83 \%$ of them were below the 50th percentile of height-for-age and $16.6 \%$ were below the 50 th percentile of weight-for-height. They concluded that $13 \%$ of the children in their sample were both stunted and wasted according to NCHS/WHO references. Distinct from other studies in urban areas, results for Manaus are consistent with the Caboclo data reported here for height-for-age, but incidence of low weight-forheight is higher in Manaus than in the Caboclo.

Murrieta et al. [36], reporting data from 1994 from Caboclo children in two rural communities on Ituqui Island, found only $2.1 \%$ of their sample of 232 children ages 0 to 10 years to present low $Z$ scores of weight-for-height, consistent with findings from this 
research. Of the sample of Murrieta et al. [36], 87.1\% was below the 50th percentile on height-for-age; the results reported here show a lower prevalence of stunting in all three Caboclo populations. Consistent with data reported here, Murrieta et al. [36] found no significant differences in the distribution of $Z$ scores between boys and girls. Data from girls of low-income families in the peri-urban region of Santarém [42] also showed nutritional patterns comparable to those of Aracampina and Santana, and similarly high rates of anemia, skin diseases, and tooth decay [44]. On studies of rural children along the Solimões river, a clear water ecosystem, Giugliano et al. [17] reported $54.7 \%$ of them to be undernourished according to NCHS/WHO reference. In the Rio Negro region, a black water ecosystem, the prevalence of undernourished children was $63.3 \%$ [18]. These prevalence rates are lower than those observed in Caxiuanã, Santana, and Aracampina.

In a general review of physical growth and nutritional status of indigenous South Amerindian populations, Santos [41] showed that overall Brazilian samples are short and light for their age compared to NCHS/WHO references. However, like the Caboclo, these Indians maintain their body proportions, as evaluated by weight-for-height. Santos reported rates of stunting in children as low as $23.7 \%$ among the Siona-Secoya of Ecuador to as high as $75.0 \%$ among the Chachi. On the other hand, low weight-forheight ranged from $0.8 \%$ among the Suruí, Gavião, and Zoró of Brazil, to $10 \%$ among the Shipibo of Peru. Weight-for-height among the populations sampled here are closer to those of Suruí, Gavião, and Zoró than to Shipibo. In both Caxiuanã and Ituqui, heightfor-age $Z$ scores are farther from the 50th percentile than weight-for-age $Z$ scores, suggesting that stunting is more severe than wasting in these populations. A pattern similar to that observed among South Amerindians. Additionally, no cases of marasmus or kwashiorkor were observed in the Ituqui populations, and the only case of PEM was a 4year-old girl from Caxiuanã.

The Caboclo groups from Ituqui Island are undergoing considerable levels of socioeconomic modification in their subsistence activities and lifestyles due to the changes in the economic characteristics of the region [14, 34, 39]. Still, despite the demographic and economic distinctions between Aracampina and Santana, their patterns of growth and nutrition are generally better than Caxiuanã. However, the better health status of Santana cannot be attributed solely to its geographic location. Overall, the results show that the floodplain groups studied are healthier than the upland group in some aspects, with the reverse being true for others. Access to more cosmopolitan lifestyles is higher among floodplain populations, but Caxiuanã experiences less seasonal influences on health, than Aracampina or Santana.

\section{Conclusions}

This is likely one of the first studies combining such a diversity of Amazonian populations and ecosystems analyzed in both seasons of the year. It is clear that both the ecological setting and the marked seasons of the year in the region have a profound impact on the lives and the health of local residents.

In general, the hypothesis presented at the outset is not supported by the data. Many children from all three groups have low weight-for-height, weight-for-age, and height-forage $Z$ scores when compared to international reference data. However, children from Santana generally are taller and heavier than children from Aracampina and Caxiuanã, respectively. The Santana group also has fewer children with chronic and acute undernutrition during both the dry and the wet seasons. When the two more traditional 
populations are compared, Aracampina children are generally taller and heavier than Caxiuanã children, even though these differences are not statistically significant. For $Z$ scores and absolute values of height and weight the children from the more traditional population are smaller and lighter than those in the more westernized groups.

Overall, children of all three groups present weights and heights well below the 50th percentile for same-age children in the NCHS/WHO reference. Apparently, children residing where more traditional subsistence activities are practiced do not receive adequate quality and quantity of nutrients for ideal growth, lagging behind children from the more westernized populations. Generally, the findings suggest an ameliorating effect of westernization, and a secondary, more subtle, effect of the floodplain environment on health and growth. Both growth and health result from complex interactions between biotic and abiotic, cultural and environmental factors, the effects of which are difficult to disentangle. Because these three populations live in different environments and are subject to varying ecological, economic, and social constraints, only longer-term studies will establish more precisely which factors most influence growth within each group.

Although this study contributes to improve our knowledge of growth and health of Caboclo populations, more research is necessary to produce a clearer picture of interactions between environment and health in Amazonian rural populations.

The results presented in this paper have been made available to local and federal governments and to NGOs. We hope this information will help in the development of more efficient policies aimed at improving the health and well-being of the participant populations.

Acknowledgment This research could not have been completed without the collaboration of many institutions and colleagues. First, thanks are due to the communities of Caxiuanã, Santana, and Aracampina for their warm reception and voluntary participation in this research. Thanks to the Brazilian National Council on Scientific and Technological Development (CNPq) for a Doctoral Fellowship to HPS, to the Museu Paraense Emílio Goeldi (MPEG), the Brazilian Institute of the Environment and Natural Resources (IBAMA) in Breves, and the Projeto Várzea/UFPA/IPAM, for their financial and logistic support. HPS thanks specially the Department of Anthropology of The Ohio State University for support during his graduate studies. Thanks are also due to David McGrath, Rui Murrieta, Pedro Lisboa, and Iranildo Oliveira for their friendship and support during field work, and to the field team (Hilton M. Jr., Perpétuo Socorro, André Ribeiro, and Eldson "Cuminho") for their dedication under the most adverse field conditions.

\section{References}

1. Adams C (2002) Estratégias adaptativas de duas populações Caboclas (Pará) aos ecossistemas de Várzea estuarina e estacional: Uma análise comparativa. Ph.D. dissertation. Instituto de Biociências, Universidade de São Paulo, São Paulo

2. Alencar FH, Yuyama LK, Nagahama D, Parente RCP (1999) Estudo antropométrico de pré-escolares da calha do rio Negro, Amazonas, Brasil. II Barcelos. Acta Amazon 29(2):293-302

3. Anjos LAS, Meirelles E, Knackfuss I, Cardoso C, Costa SG (1989) Indicadores de gordura corporal em crianças de 7 a 11 anos vivendo em condições sócio-ambientais diferentes no Rio de Janeiro, Brasil. Ciênc Cult 41(12):1179-1188

4. Barker DJP (1998). Mothers, babies, and health in later life, 2nd edn. Churchill Livingston, New York

5. Bogin B (1999) Patterns of human growth, 2nd edn. Cambridge University Press, Cambridge

6. Cameron N, Demerath W (2002) Critical periods in human growth and their relationship to diseases of aging. Yearb Phys Anthropol 45:159-184

7. Chibnik M (1991) Quase-ethnic groups in Amazonia. Ethnology 30:167-182 
8. Coitinho CD, Leão MM, Recine E, Sichieri R (1991) Condições nutricionais da população Brasileira: Adultos e idosos. Ministério da Saúde, Instituto Nacional de Alimentação e Nutrição, Brasília

9. Cuff T (1995) Introduction: historical anthropometrics - theory, method, and the state of the field. In: Komlos J (ed). The biological standard of living on three continents: Further explorations in anthropometric history. Westview, Boulder

10. Engstron EM, Anjos LA (1999) Deficit estatural nas crianças brasileiras: relação com condições sócioambientais e estado nutricional materno. Cad Saude Publica 15(3):559-567

11. Espinosa MVP (1996) La crianza de los niños menores de seis años em Latinoamerica. Organización de los Estados Americanos, Santiago

12. Frisancho RA (1993) Human adaptation and accommodation. University of Michigan, Ann Arbor

13. Frisancho RA (1999) Anthropometric standards for the assessment of growth and nutritional status. University of Michigan, Ann Arbor

14. Gentil JML (1988) A juta na agricultura de Várzea na área de Santarém, médio Amaznas. Bol Mus Para Emilio Goeldi Antropol 4(2):118-199

15. Giles E, Friedlaender J (eds) (1976). The measures of man: Methodologies in human biology. Schenkman, Cambridge

16. Giugliano R, Albuquerque H, Shrimpton R (1978) Estudo antropométrico, clínico e de padrões alimentares em um grupo de escolares de Manaus, 1976. Acta Amazon 8(1):75-82

17. Giugliano R, Giugliano L, Shrimpton R (1981) Estudos nutricionais das populações rurais da Amazônia. I. Várzea do rio Solimões. Acta Amazon 11(4):773-788

18. Giugliano R, Shrimpton R, Marinho H, Giugliano L (1984) Estudos nutricionais das populações rurais da Amazônia. II. Rio Negro. Acta Amazon 14(3-4):427-450

19. Goldstein H (1986) Sampling for growth studies. In: Falkner F and Tanner JM (eds) Human growth: A comprehensive treatise. Plenum, New York

20. Gonzales G, Valera J, Rodriguez L, Vega A, Guerra-Garcia R (1984) Secular change in growth of native children and adolescents at high altitude Huancayo, Peru (3,200 meters). Am J Phys Anthropol 64:4751

21. INAN (1990a) Pesquisa nacional sobre saúde e nutrição (resultados preliminares) 2nd edn. Instituto Nacional de Alimentação e Nutrição do Ministério da Saúde, Brasília

22. INAN (1990b) Perfil de Crescimento da População Brasileira de 0 a 25 anos. Instituto Nacional de Alimentação e Nutrição do Ministério da Saúde, Brasília

23. Jatene SR, Britto RC, Moura EAF, Sá EV, Diniz A (1993) A meia vida da criança na Amazônia. Série Pobreza e Meio Ambiente na Amazônia, vol 3. UNAMAZ, UFPA, Belém

24. Júnior ULS (1996) A Eficiência no Uso dos Recursos Pesqueiros pela População Ribeirinha da Ilha do Ituqui (Santarém, PA). Preliminary Report. Projeto Várzea/UFPA/IPAM: Santarém

25. Lei DLM, Freitas IC, Chaves SP, Lerner BR, Stefanini MLR (1997) Retardo do crescimento e condições sociais em escolares de Osasco, São Paulo, Brasil. Cad Saude Publica 13(2):277-283

26. Lima-Ayres DM (1992) The social category Caboclo: History, social organization, identity, and outsider's social classification of the rural population of an Amazonian region (The Middle Solimões). Ph.D. dissertation. University of Cambridge, Cambridge

27. Lisboa PLB (ed) (1997) Caxiuanã, vol 1. Museu Paraense Emílio Goeldi/CNPq, Belém

28. McGrath D (1994) Projeto Várzea: Lake reserve and community based management of Várzea resources, Ituqui, Brazil. ODA/WWF proposal (WWFBR0604)

29. Monteiro CA, Benício MHD, Gouveia NC (1992) Saúde e nutrição das crianças brasileiras no final da década de 80. In: CA Monteiro, MHD Benício and NC Gouveia (eds.). Aspectos da Saúde e Nutrição no Brasil. Ministério da Saúde: Brasília

30. Monteiro CA (1997) O panorama da nutrição infantil nos anos 90. Cad. de Pol. Soc. Série Documentos para Discussão, No. 1. Unicef, Brasília

31. Monteiro CA (1999) Evolução do perfil nutricional da população brasileira. Saúde em Foco. Ano VIII $18: 4-8$

32. Moore SE, Cole TJ, Collison AC, Poskitt EME, McGregor IA, Prentice AM (1999) Prenatal or early postnatal events predict infectious deaths in young adulthood in rural Africa. Int J Epidemiol 28:10881095

33. Murrieta RSS (1994) Diet and subsistence: Changes in three Caboclo populations on Marajo Island, Amazonia, Brazil. Master's thesis, University of Colorado at Boulder, Boulder

34. Murrieta RSS (1998) Food consumption among Caboclo communities on Ituqui Island, Amazonia, Brazil. Am J Hum Biol 10(1):132-133

35. Murrieta RSS, Dufour D, Mcgrath D (1996) Práticas e discursos de programas nutricionais de intervenção na Amazônia Brasileira: Paradigma científico ou agenda institucional? Manuscript

36. Murrieta R, Neves WA, Dufour D (1998) Status nutricional infantil em três comunidades ribeirinhas da ilha de Ituqui, Amazônia, Brasil. Bol Mus Para Emilio Goeldi Antropol 14(2):3-19 
37. National Center for Health Statistics (NCHS) (1977) NCHS growth curves for children - birth 18 years. Vital and Health Statistics Series 11 - No 165. U.S. Department of Health, Education and Welfare - Public Health Service, Washington

38. Neves WA (1992) Antropologia ecológica de populações ribeirinhas do estuário do Amazônas: Subsistência e adaptação. Scientific report presented to CNPq, Brazil

39. Nugent S (1993) Amazonian Caboclo society: An essay on invisibility and peasant economy. Berg, Oxford

40. Probart C (1993) Research issues in nutrition. Coll Antropol 17(2):363-370

41. Santos RV (1993) Crescimento físico e estado nutricional de populações indígenas brasileiras. Cad Saude Publica 9(1):46-57

42. Silva HP (1995) Physical growth and health aspects of girls from a day care center in Santarém: comparison with other samples from Brazil and Ecuador. Am J Hum Biol 8(1):129

43. Silva HP (1999) Bioanthropological aspects of ecologically diverse Amazonian peasant populations. Am J Phys Anthropol (Suppl) 28:251-252

44. Silva HP (2001) Growth, development, nutrition and health in Caboclo populations from the Brazilian Amazon. Ph.D. dissertation. Department of Anthropology. The Ohio State University, Columbus

45. Silva HP (2002) Aspectos demográficos e médico-epidemiológicos dos residentes na Floresta Nacional da Caxiuanã, Melgaço, Pará. In: Lisboa PLB (ed) Caxiuanã: Populações tradicionais, meio físico e diversidade biológica. Mus Para Emílio Goeldi/MCT, Belém, pp 77-94

46. Silva HP, Padez C (2006) Secular trends in age at menarche among Caboclo populations from Pará, Amazonia, Brazil: 1930-1980. Am J Hum Biol 18(1):83-92

47. Silva HP, James GD, Crews DE (2006) Blood pressure, seasonal body fat, heart rate, and ecological differences in Caboclo populations of the Brazilian Amazon. Am J Hum Biol 18(1):10-22

48. Siqueira AD (1997) Ecology of food and nutrition: Patterns of land use and nutritional status among Caboclo populations on Marajó Island, Pará, Brazil. Ph.D. dissertation. Department of Anthropology, Indiana University, Bloomington

49. Wagley C (1963) An introduction to Brazil. Columbia University Press, New York

50. Wagley C (ed) (1974) Man in the Amazon. University Press of Florida, Gainesville

51. Weiner JS, Lourie JA (eds) (1981) Practical human biology. Academic, New York

52. WHO (1995). Physical status: The use and interpretation of anthropometry. WHO Technical Series No 854. World Health Organization, Geneva 